\title{
Students Facing the Future: New Pedagogical Strategies in Forming a University Upbringing Culture
}

\author{
Tatiana Voronchenko ${ }^{1, *}$, Galina Lavrova ${ }^{2}$ \\ ${ }^{1}$ Literature and Journalism Department, Transbaikal State University, Chita, Russian Federation \\ ${ }^{2}$ Economics and Management Department, Vladimir University for Tourism and Hospitality, Vladimir, Russian Federation \\ *Corresponding author: tavoronch@mail.ru
}

Received March 31, 2015; Revised April 22, 2015; Accepted May 07, 2015

\begin{abstract}
Global challenges of the $21^{\text {st }}$ century show that the upbringing of a harmonious personality is a central problem for the contemporary higher education system. It is particularly relevant for Russia, which has experienced recent large shocks, associated with the breaking of social order. In this regard, there is a need to find new pedagogical strategies to support the development of a student's personality, in order to intensity the process of forming positive value orientations among young people. This requires harmonizing the educational process and unifying intellectual, aesthetic and moral components. Socio-anthropological, structural-systematic and axiological approaches are accounted by the need for understanding the pedagogical strategies of achieving the harmonious personality in the context of modern university educational space through the systematization of specific empirical facts and analysis of existing Russian, American and European scientific theories. We relied on the scientific works of Russian, American and European authors; empirical material taken from the practice of Vladimir University for Tourism and Hospitality. Despite some differences in the interpretation of the terms "education", "upbringing" and "pedagogy" in American and Russian cultures, it is evident that they have a common focus on the humanization of personality. As a result of studying and summarizing the scientific literature in the field of research and interpretation of the practice of Vladimir University for Tourism and Hospitality, there were identified practical recommendations. These recommendations are the pedagogical strategies for the establishment of a harmonious personality in the context of the upbringing culture of the university: strengthening the relationship of academic and upbringing activities; improvement of the intellectual, aesthetic and moral components of the teacher's personality; introduction of the cultural component into the curriculum and introduction of tourist activities into the educational space of the university. The above strategies will help, in our opinion, to build the upbringing culture of university that will guide students to the harmonious development of inner life, positive self-identification and the development of moral values.
\end{abstract}

\section{Keywords: pedagogical strategy, upbringing work, extracurricular activity, values, harmonious personality}

Cite This Article: Tatiana Voronchenko, and Galina Lavrova, "Students Facing the Future: New Pedagogical Strategies in Forming a University Upbringing Culture.” American Journal of Educational Research vol. 3, no. 5 (2015): 652-657. doi: 10.12691/education-3-5-19.

\section{Introduction}

Active and positive student self-construction in the context of the contemporary university educational space is a central issue in terms of evaluating the work of the university. Therefore special attention should be paid to extracurricular (upbringing) work, aimed at organizing activities to develop scientific, social, sports, and creative abilities of students. The position of the American representatives of the academic school (University of Michigan and the University of Arizona) is of great interest. J.S. Eccles and B.L. Barber have examined the correlation of different extracurricular activities and the value of positive and negative indicators of development. They found that “...involvement in these types of prosocial activities was linked to positive educational trajectories and low rates of involvement in risky behaviors" [1].
Upbringing activity is an important structural piece of the contemporary university activity. Analyzing and evaluating empirical data regarding extracurricular university activity and taking into account terminological lack of continuity of such terms as "education", "upbringing" and "pedagogy" make it necessary to distinguish these notions. There are some differences in the interpretation of these notions in two cultures: the United States and Russia. We have tried to show how they are perceived in two cultures, relying upon Russian and English-language sources and the personal experience of teaching at the University of California of one of the authors (T. Voronchenko, Fulbright UCSD in 1998, Fulbright UCSB 2008). The dictionary of Russian language by the Russian Academy of Sciences defines the word "education" in two ways: as the process of learning, training, education, and as a body of knowledge resulting from training [2]. A. Novikov, a member of the Academy 
of Sciences, defines upbringing as "the direction of the personal development - the process and the result of" in his book "Pedagogy: a dictionary of basic concepts" [3]. According to him, "the direction (aspects) of education are defined in accordance with the self-other orientation system including both object and subject" [3]. The Russian Pedagogical Encyclopedia defines learning as a teacher and a students' task-oriented activity that provides the development of personality and personal education and upbringing [4]. This encyclopedia interprets the concept of "education" that is similar to the meaning of "upbringing" and "learning" cited above: "Education is a pedagogically organized process of socialization put into practice on behalf of the individual and society. Education combines learning and upbringing to ensure cultural continuity of generations and person's readiness for social and professional roles. Education helps the individual to assimilate a set of moral and cultural values appropriate to personal interests and social expectations [[4],4a].

According to the American educational tradition, the concept of "education" includes at least five variable components: 1) the process and the result of learning (by the teacher); 2) the process and the result of learning (by students); 3) any development by the learning process (in any educational institution); 4) any person's progress in knowledge and abilities; 5) a unified institution along the politics, medicine, agriculture and the economics. The notion of "pedagogy" is often used when speaking of the learning process. In the Russian educational tradition, the concept of education historically covers the same features but the idea of upbringing has been paid more attention to, especially in the $20^{\text {th }}$ century. Along with the development of the general concept of education, there are the categories of "pedagogics" (as a science) and "pedagogy" (both as a science and as a process). Currently the term "pedagogy" implies two ideas: didactics (learning) and upbringing. Unlike the United States, where the concept of "education" is a multi-faceted category now, the concept of "pedagogy” in Russian has been divided into "learning” and "upbringing" since the $20^{\text {th }}$ century. Moreover, the recent revival of Russian pedagogy has attracted special attention to the process of upbringing [5].

The purpose of this article is to examine the problems of contemporary students' upbringing based on the activity of Vladimir University for Tourism and Hospitality. Despite the rapid changes of the current reality and a time of growing political tension in the world, Russia is continuing the improvement of higher education in accordance with international standards and aims to deliver the achievements in the world educational space. Russian policy in the field of education is aimed at creating a mechanism for a sustainable model of education that meets the requirements of the $21^{\text {st }}$ century. Upbringing activity at the university, aimed at improving the moral and ethical ideas of students focusing on human values and humanistic ideals, plays an important role in this process.

The problem of the upbringing of harmonious personality is relevant throughout the history of mankind. Each new generation with all the similarities of age characteristics, differs from the previous one in its ideological positions, values, and ways of self-realization in the new conditions of life. Back in 470 BC, Socrates lamented: "Our youth now love luxury. They have bad manners, contempt for authority; they show disrespect for their elders; they contradict their parents, gobble up their food and tyrannize their teachers" [6]. The problem is relevant for any country today in respect to the new generation, including Russia. In recent decades, due to a sharp breaking of the socio-political system in Russia (1990s) and the loss of the spiritual traditions among young people, there are widespread consumer ideals and reduction in the level of education and manners. This indicates a certain immature attitude to life in general, when the values targeting young people are replaced by a shallow, light, unscrupulous attitude toward life.

Contemporary university students are a good example of this issue. As the researchers note, contemporary Russian students are the most problematic group in society, which is undergoing dynamic internal changes and the increasing complexity of relationships with all the elements of the economic, socio-political, cultural and other structures of society $[7,8,9,10]$. This is largely because the students do not take an independent place in the production system, their status is temporary, and social status of students and their specific problems are determined by the nature of the social order that depends on economic and cultural development of the country.

The studies of contemporary Russian sociologists (Arkharova, Borisova, Martynova, Nizovskikh) argue about the disturbing trend of disorientated value consciousness among the student audience. Analyzing the system of life principles among the group of students of Vyatka State Humanitarian University, N. Nizovskikh found that some of them are deliberately chose an orientation toward dishonesty, exploitation [11]. A need for creative work is minimally expressed, there is no desire for the productivity of work. Students find it difficult to articulate their relationship to nature, the State [11]. E. Martynova, L. Arkharova noted that the values of creativity, the happiness of others, the love of God, the beauty of nature and art are rejected by the students $[13,14]$. It is explained by reduction of prestige of cultural and creative activities among youth, low status of altruistic position in life, and by that higher education pays low attention to the spiritual and creative development of students.

E. Martynova questioned about 1,500 students of different courses and divisions at Moscow State Open University and revealed a significant group of respondents (16\%) with a low understanding of life, who have difficulty in finding the meaning of life for themselves in any lifetime: past, present, future. They do not believe in their own opportunity to exercise control over the lives. Few students are aware of the need and importance of the transformation of their inner world, the search for new opportunities for self-realization in professional work. Apparently, no one of the surveyed by E. Martynova bounds him- or herself meaning of life with the implementation of any kind of their creative and professional abilities. The author has obtained important data about that within the growth of the meaningfulness of life of the students their centration, irritability, authoritativeness, anxiety, propensity to compete decreases [13].

M. Borisova studied the hierarchy of needs and life values of students and found that there is a dominance of 
organic needs, involving selfish care only about themselves and proprietary attitude towards people [15].

Combining young people about the same age (17-25 years) and with a similar level of education, students differ from other groups of learners very much. The primary objective is to obtain a higher professional education that meets the needs of an intelligent person, allowing them to compete in the job market and to work effectively in the chosen field. Compared to other groups of young people, students take a much more serious attitude to life in relation to most social problems. Common goals in higher education, the single character of the work such as the study, lifestyle, and active participation in public university activities promote the development of students' solidarity. This manifests itself in a variety of forms in the collective activity of students.

Studentship is a period of intensive dialogue, forming friendship and romantic relationships, many of which have been lasting for many years and become the basis of social support and interaction. At the same time, the immature attitudes to life of the adolescent in the system of social interaction may be noted.

The basis of the material used for this study is empirical data obtained by Vladimir University sociologists. S. Zavrazhin, N. Davedyanova and M. Nazarov have examined the contents of the image of the future family, interviewing female students of Vladimir State University for the Humanities. They found that about 60\% of respondents approve of premarital sexual relations, as a way to make a more responsible and correct choice of their future husband and so that their marriage does not lead to adultery. $78 \%$ of respondents believe that the selfexpression of spouses is more important than the interests of the children. It was found that many students are tolerant of using foul language, substance abuse, sexual deviancy and the possible legalization of prostitution [9].

These trends are not local ones and they are seen in universities across the country. As rightly noted by individual researchers [10], [8], spiritual and moral crisis among students is due to not only the loss of existential points in Russian society, but also the contradictions which accumulated in the national higher education system:

- the necessity of spiritual and moral upbringing vs. the lack of the psycho-pedagogical formation mechanism of the value-semantic sphere of the future specialist declared by the state educational standard;

- students' pursuance of searching for the meaning of life vs. the educational process, ignoring this need, focused on intellectual development;

- mosaic content of university knowledge of the spiritual human world, including knowledge of the spiritual world of a man from the orthodox point of view vs. the need for systemic integration into culture with a clear understanding of the hierarchy of values.

As the authors' teaching experience has shown, teaching staff is having trouble in upbringing work with students, because traditional upbringing schemes do not work in the present conditions.

Thus, the results of sociological studies took place in the Vladimir University for Tourism and Hospitality (1000 students were tested from 1997 to 2013 by G. Lavrova and E. Ignatov), and the teaching experience of the authors show the existence of the problem of finding sense and values among contemporary Russian students. In this regard, there is a need to find new pedagogical strategies to foster positive values-based points of students, which, in our opinion, requires harmonization of the entire educational process in the unity of its intellectual, aesthetic and moral components. The problems of formation of a new culture of upbringing at the university and the scientific and methodological support and staff of upbringing work are very important.

\section{Approach}

The necessity of thinking about possible perspective pedagogical strategies to achieve the harmonious personality in the context of modern university educational space through the systematization of specific empirical facts and analysis of existing Russian, American and European scientific theories, have led to the choice of complex approach based on socio-anthropological, structural and systemic and axiological approaches. The socio-anthropological approach to the problem helps to identify, organize and compile the concrete empirical evidence about the state of contemporary society and the role and behavior of the student environment as a reflective subject of social processes. The structural and systemic approach to the development of the individual in school and extracurricular activities involves the method of analysis of knowledge systems (the study and synthesis of scientific literature in the field, methodological and theoretical framework of the study), and the application of scientific theories to construct theoretical models of teaching strategies, planning the empirical part of the study and interpretation of the results. The axiological approach focuses on the study of teaching strategies as positive factors in the formation of values of students in the context of the basic values that are based on the fact that a man is regarded as the supreme value of society and the aim of social development.

Development of teaching strategies can be traced by the authors in four areas:

1. strengthening the relationship of academic and upbringing activities;

2. improvement of the intellectual, aesthetic and moral components of the teacher's personality;

3. introduction of the cultural component into the curriculum;

4. introduction of tourist activities into the educational space of the university.

\subsection{Strengthening the Relationship of Academic and Upbringing Activities}

There is a stereotype about upbringing activities at the university. This is, that the upbringing process is moved away from the general flow of pedagogical processes, its functional role is limited and considered as optional, or worse, it is treated as something that hinders the “educational process" [12]. World scholars in recent years do not support this point of view such as Astin [16], Tinto [17,18], Pascarella [19] and Weidman [20]. Sociological theories put forth by scholars such as Astin [16], Tinto [17], Pascarella [18] and Weidman [20] offer important insight on how to better understand student development 
and change within a higher education setting. These theories describe a number of factors relating to students' academic achievement, interactions with faculty/peers, and their ability to become involved in extracurricular activities in relation to their academic and social outcomes. From a sociological perspective, these factors draw attention to student development within a higher education context in terms of changes in their behavior, attitudes, skills, values, goals, commitments” [21].

On this account contemporary pedagogical technologies are student-oriented. One of the ways to implement such an education is to build a process of learning and upbringing on the integrative basis. The integration makes it possible not only to expand the content of education, including social and philosophical, psychological, pedagogical, economic, historical and other knowledge in a particular discipline, but also affects the personal development of the student.

Teachers in Russia have always been upbringing-tutors, but today education can and should be understood not only as a transfer of experience and value judgments from the older to the younger generation, but also as a collaboration of teachers and students in the field of cocurricular and extracurricular activities [12]. In recent American (R. Bell, 2011), Canadian (W.B. Strean, 2011) and Russian (M. Liga, T. Voronchenko, Y. Zakharova, 2014) studies, we see the research work in the same direction. Works by American scientists K.C. Williams and C.C. Williams from California State University and University of Wisconsin confirm this idea: "the role of teachers seems to be shifting from preprogrammed knowledge dispensers to instead managers of student learning and the learning environment” [25].

The basic principle of the Vladimir University for Tourism and Hospitality is the integrity of academic and upbringing work. All major personality traits are formed during learning and upbringing activities. By forming the upbringing work at the university the coordinating role of administration, board of supervisors and student council is increasing.

Thus, through the strengthening of the relationship between academic and upbringing activities, the use of such methods of upbringing work, which would be aimed at the development of scientific, social, sporting and creative abilities of students will promote the active and positive self-construction of students. This can be a new pedagogical strategy for the formation of harmonious personality at the university.

\subsection{Improvement of the Intellectual, Aesthetic and Moral Components of the Teacher's Personality}

Personal qualities of the teacher are of great importance for the effectiveness of the student's positive self-identification. The Russian educator and founder of scientific pedagogy in Russia, K. Ushinsky confirmed that: "Only personality is able to raise a personality” [26]. Authority of the teacher, pedagogical culture, pedagogical ethics and tact are the components of pedagogical creativity, pedagogical skills, forming a productive, meaningful impact on consciousness and mentality of the student.

The effectiveness of the upbringing component depends on the creativity of the teacher and his or her ability to see not only informative, but also emotional, intellectual, aesthetic, and moral issues in the course [27]. Such a situation is possible if the teacher is not only highly professional, but is also able to solve upbringing problems simultaneously. However, the authors' personal experience at the university is that real educational process involves mainly the acquisition of knowledge, but the development of students' professional skills is not included. Therefore, today we can see that processes of learning and upbringing are characterized by a low level of integration and that authoritarian "teacher-student" relationships are dominant.

A teacher's attitude to work, to other people, his or her professionalism, erudition, self-discipline and creative skills contribute to the formation of such creative qualities of students. Intelligence, communication skills and tact create such an atmosphere between teachers and students, that teachers and students are equal subjects of a single process of education, upbringing and self-development [28].

Sharing the position of these authors, we are convinced that in order to develop a holistic worldview, the spiritual and moral culture of the younger generation pedagogue must have not only knowledge and practical skills themselves, but also significant moral and ethical, spiritual and personal qualities that will have a direct positive impact on the process of forming of a student's harmonious personality. The development of such qualities of teachers is a way for providing a new upbringing culture in high schools, aimed at forming positive values among students.

\subsection{Introduction of the Cultural Component into the Curriculum}

The upbringing process in a university will be successful if most courses include aspects aimed at the development of certain skills, such as moral, psychological, pedagogical and legal skills. Curricula should include specialized courses with cultural and regional components (e.g. Psychohygiene, Tourist Regional Studies, Culture Studies, Ethics and Business Relationships, Legal Aspects of Tourist Activities, Code of Tourist Services, etc.). Thus, during the courses it could be possible to provide civil, patriotic, spiritual and moral education [11].

The cultural component is an undoubted condition for the success of the upbringing process, as it sets the parameters of pedagogical influence on students, so they could learn the values, ideals, patterns of behavior of professional and actively resist the negative interference of the environment [29]. Dutch researcher V. Veugelers supports this idea in his article "Moral values in teacher education" (2010): "Values are expressed in attitudes that become visible in opinions and concrete behavior. Attitudes based on moral values refer to being in society, being with others, and the reflective view on one's own identity. Adding value to development implies that human development is seen not as a natural biological process, but as a process of giving meaning to the world. It is a process of growing into cultural practices and positioning oneself by articulating what is valuable, it is a personal reconstruction of cultural practices and narratives" [30].

Introduction of the cultural component into the curriculum, in our opinion, should be a mandatory 
addition of elements providing the development of cultural competence in curricula. Expanding the cultural field of the student should be a pedagogical strategy that will develop an open, tolerant view of the world, which is a feature of a harmonious personality.

\subsection{Introduction of Tourist Activities in the Educational Space of the University}

According to the Russian Federation State program "Development of Culture and Tourism" for 2013-2020, the development of tourism is an important means of introducing citizens to the world culture. One of the objectives of the program is to improve the quality and accessibility of services in domestic and international tourism, creating favorable conditions for sustainable development of culture and tourism. All these tasks are entered into one main goal of the state program - the implementation of the strategic role of culture as a spiritual and moral foundation for personal development and the state [31].

The matter of personal development in the context of tourism and culture are closely related to the education sphere. Aims of tourist activity have something in common with the aims of personality's upbringing. This fact confirms the pedagogical value of tourism once again. Tourism is essentially a source of moral, aesthetic, physical, social and economic development of the personality. Deeper understanding of the various processes taking place in society can be achieved by tourism activities. It can also be considered one of the sources of human culture. In this regard, contacts and meetings with people of different nationalities and different cultures are very important.

The tourist upbringing space has unique opportunities for the development and formation of the student's personality in the university environment. Doctor of Education Y. Lagusev lists them as the following:

- freedom to make decisions about entering the tourist upbringing space;

- freedom to choose the type of tourist activity - one that would allow to achieve the highest expression or satisfaction;

- construction of dialogue with people of different ages and social groups;

- more intense living of different social roles;

- opening up subspaces: cultural, natural, information, etc. [32].

Tourism gives people access to the achievements of human culture. Recreational, social, cultural and historical tourism objects form a new space with special upbringing potential properties. In our opinion, a tourist upbringing space cause cultural and human values to have active influence on a student, stimulating processes of his or her self-actualization, self-realization and self-improvement.

It is necessary to emphasize the two-way communication system of relations in the upbringing process in tourism. It is known that feedback is an essential mechanism of all learning and upbringing. Information obtained by feedback corrects the process of upbringing. There are two major links in the feedback the link of transmission of feedback and the link of receiving it. The researchers argue that receiving feedback is largely determined by how a person "submits" to the other one's understanding. For example, students, who completed an internship abroad and understood the lack of certain knowledge and skills, require teachers to provide these knowledge and skills. Thus, the formal educational process transfers into a student-centered process.

At the Vladimir University for Tourism and Hospitality, the learning process and personality's formation is focused on professional practical training. The students are able to obtain work skills in the field of tourism activity. The combination of theoretical and practical training is an organic synthesis, which is secured through curricula, programs, and various kinds of practices, training at tourist institutions and organizations both in Russia and abroad.

\subsection{The Strategy of the Upbringing Work at Vladimir University for Tourism and Hospitality}

Varied experience gained at the Vladimir University for Tourism and Hospitality in more than fifteen years, determines the strategy of upbringing work in two main positions: 1) active opposition of "market economy" culture, which carries a pronounced anti-social connotation, leading to deformations of personal development, replacing the system of value relations; 2) upbringing work is accompanied by the formation of cultural competence of future professionals.

The main objective of the upbringing work program at the University is adopted coordination of learning and upbringing processes. We are talking about the formation of a common space of the cultural and professional community that fosters professional self-actualization and freedom to choose the individual experience of cultural skills.

The upbringing process presupposes social-role attitudes and formation of values and motivations. Upbringing activities focus on the formation of competitive specialists, ready for dynamic, social and professional mobility, to the constant and regular change of activity as well as for the search of optimal, effective solutions in a highly competitive environment.

There are a few main features of upbringing work at the Vladimir University for Tourism and Hospitality. First, upbringing work relies on the student government in order to overcome isolation and encourages fusion. Second, upbringing interaction begins with the first day of the student's stay at university. Third, the development of positive value orientations of students is in the spotlight. Fourth, moral and material incentives are a mechanism for enhancing the efficacy of upbringing activities.

These characteristics suggest that the upbringing system of the University based on the principles of humanistic orientation, cultural conformity, effectiveness of social interaction and continuity with nature. On this basis, we propose to put the following pedagogical strategies into practice for upbringing activities, developed at the Vladimir University for Tourism and Hospitality:

- strengthening the relationship of academic and upbringing activities for the fullest development of cultural and spiritual values by the students and teachers;

- stimulating the process of self-knowledge, the development of individual lifestyle and behavior, i.e. facilitating the efforts which the student is taking for selfdetermination, self-assertion and self-realization; 
- improvement of the intellectual, aesthetic and moral components of the teacher's personality;

- spiritual upbringing of students, taking into account national values; the idea of openness to other cultures in the university space;

- introduction of the cultural component into the curriculum;

- introduction of tourist activities into the educational space of the university in order to form a positive outlook, values and beliefs of students and enrichment of their inner world for a more open view of the surrounding world.

\section{Conclusions}

During the study, we were guided by the fact that the modern university is a form of joint activity of teachers, students, administrators and support staff, organizing and providing the learning and upbringing process for students, in turn giving them the socially significant values of science, culture and morality. Thus, by studying the experience of building upbringing work at the Vladimir University for Tourism and Hospitality, we believe that it can implement pedagogical strategies that can identify the real way to mitigate the moral crisis in the student community. Pedagogical strategies of the modern university: strengthening the relationship of academic and upbringing activities; improvement of the intellectual, aesthetic and moral components of the teacher's personality; introduction of the cultural component into the curriculum; and the introduction of tourist activities into the educational space of the university - will help, in our opinion, to build an upbringing culture of the university, which will contribute to the harmonious development of inner peace, positive self-identification and the development of moral values.

\section{References}

[1] Eccles, J.S., Barber, B.L., "Student Council, Volunteering, Basketball, or Marching Band What Kind of Extracurricular Involvement Matters?” Journal of adolescent research, 14(1), p. 10-43, 1999.

[2] Yevgen'yeva, A., Slovar' russkogo yazyka [Russian Language Dictionary], Russian Academy of Sciences, 1999, p. 560.

[3] Novikov, A., Pedagogika: slovar' sistemy osnovnykh ponyatiy [Pedagogics: System of Main Concepts Dictionary], Publisher center of IAT, 2013, 268 p., p. 26.

[4] Davydov, V., Rossiyskaya pedagogicheskaya entsiklopediya [Russian Encyclopedia of Pedagogics], GRE Publisher, 1993, 607 p., p. 67.

4a. Davydov, V., Rossiyskaya pedagogicheskaya entsiklopediya [Russian Encyclopedia of Pedagogics], GRE Publisher, 1993, 607 p., p. 62.

[5] Sinagatullin, I.M., Teaching Is More Than Pedagogical Practice: Thirty-Three Strategies for Dealing With Contemporary Students, R\&L Education, 2009, 254 p., p. 85.

[6] Dushenko, K., Mysli i izrecheniya drevnikh [Ancient Thoughts and Aphorisms], Litres, 2013, p. 14

[7] Lisovskiy, V., "Dinamika sotsial'nykh izmeneniy [The Dynamics of Social Changes]," Sociological Studies, 2004, Moscow.

[8] Belyaeva, M., "Voprosy vysshego pedagogicheskogo obrazovaniya $\mathrm{v}$ sovremennoy Rossii [The Issues of Higher Pedagogical Education in Contemporary Russia]," St Tikhon's University Review, 2 (33), p. 18-24, 2014.

[9] Zavrazhin, S., Daved'yanova, N., Nazarova, M., Obraz budushchey sem'i u studentok vuzov: materialy sotsial'no- psikhologicheskogo issledovaniya [Image of Future Family among University Students: Social-Psychological Studies Materials], Vladimir, 2008, $32 \mathrm{p}$.

[10] Korneva, V., Razvitiye tsennostnykh oriyentatsiy studencheskoy molodezhi $v$ pedagogicheskom protsesse vuza [The Development of Value Orientations of Youth Within the Pedagogical Process in University], Khabarovsk State University, 2005, p. 22.

[11] Nizovskykh, N., "Zhiznennyye printsipy i tsennostnyye oriyentatsii studencheskikh grupp [Life Principles and Value Orientations of Student Groups],"Psychology Issues, 5, p. 73-82, 2013.

[12] Sidorova, I., "Vospitaniye na osnove sotrudnichestva [Upbringing Based on Cooperation]," Higher Education in Russia, 7, p. 79-82, 2009.

[13] Martynova, E., Smyslozhiznennyye oriyentatsii kak faktor lichnostnoy podgotovki studenta pedvuza $k$ professional'noy deyatel'nosti [Meaning-of-life Productive Orientations as a Factor of Personal Preparation of Pedagogy Student to Professional Activity], Stavropol, 2006.

[14] Arkharova, L., "Tsennosti obrazovaniya studencheskoy molodezhi [Values of Education of Student Youth]", Pedagogy and Psychology as a Resource for Development of Modern Society, Ryazan, 2014.

[15] Borisova, M., Mirovozzreniye studentov kak faktor sistemnoy ustoychivosti lichnosti [Student Worldview as a Factor of System Stability of a Person], Stavropol, 2006.

[16] Astin, A., Assessment for Excellence: the Philosophy and Practice of Assessment and Evaluation in Higher Education, Rowman \& Littlefield Publishers, 2012, p. 380.

[17] Tinto, V., "From theory to action: Exploring the institutional conditions for student retention," Higher education: Handbook of theory and research, Springer Netherlands, p. 51-89, 2010.

[18] Tinto, V., Completing College: Rethinking Institutional Action, University of Chicago Press, 2012, p. 228.

[19] Pascarella, E.T., Terenzini, P.T., How college affects students, Vol. 2, San Francisco: Jossey-Bass, 2005, p. 545.

[20] Weidman, J., "Socialization of Students in Higher Education: Organizational Perspectives,” The Sage Handbook for Research in Education: Engaging Ideas and Enriching Inquiry, p. 253-262, 2006.

[21] Rampersad, C.M., Diversity in Question: Inclusionary and Exclusionary Social Interactions among International Graduate Students, ProQuest, 2007, p. 349.

[22] Bell, R., "The Power of Religion, Upbringing, Certification, and Profession to Predict Moral Choice," Journal of Legal, Ethical and Regulatory Issues, 14 (1), p. 1-24, 2011.

[23] Strean, W.B., "Creating Student Engagement? HMM: Teaching and Learning with Humor, Music, and Movement," Creative Education, 2, p. 189, 2011.

[24] Liga, M., Voronchenko, T., Zakharova, Y., "Educational Policies for Providing the Quality of Life," CBU International Conference Proceedings, 2, p. 162-169, 2014.

[25] Williams, K.C., Williams, C.C., "Five Key Ingredients for Improving Student Motivation," Research in Higher Education Journal, 12, p. 1-23, 2011.

[26] Ushinskiy, K.D., Pedagogicheskiye sochineniya [Pedagogical Works], Pedagogics, 1990, vol. 5, 525 p.

[27] Batrakova, S.N., “Obrazovatel’nyy potentsial pedagoga kak 'cheloveka kul'tury' [Educational Potential of Pedagogue as a "Man of Culture]," Higher Education in Russia, 5, p. 105-108, 2009.

[28] Minzaripov, R.G., Ivshina, G.V., "Gumanitarnaya sreda klassicheskogo universiteta [Humanitarian Environment of Classic University],” Higher Education in Russia, 5, p. 42-50, 2009.

[29] Yurchenko, Y., "Vospitatel'naya Rabota Vuza v Inter'yere goroda-kurorta [Upbringing Work in the University within the Resort City]," Higher Education in Russia, 10, p. 101-104, 2005.

[30] Veugelers, W., "Moral Values in Teacher Education," International Encyclopedia of Education, 7, p. 650-655, 2010.

[31] Postanovleniye Pravitel'stva RF [Government Decree Russian Federation Government], April 15, 2014, № 317.

[32] Lagusev, Y., Vospitatel'nyy protsess $v$ turistskom professional'nom obrazovanii [Upbringing Process in Touristic Professional Education], Sovetskiy Sport, 2000, 272 p. 